Article

\title{
Ethics of Worldliness: The Ethical Character of Arendt's Political Thought
}

Yosef Keladu

\begin{abstract}
This paper aims to reconstruct Arendt's ethics of worldliness from her specific way of thinking about the world and how judging an action takes place in it. For Arendt, by thinking we show our responsibility for the world into which we are thrown. In judging a political action we are directed by ethical constraints to come from the world itself and the verdict of spectators. That means, when we judge we should be aware of the things that an action could bring to the public realm and what others might say about it.
\end{abstract}

Keywords: Arendt, ethics of worldliness, thinking, responsibility

\section{Introduction}

$\mathrm{I}$

n The Human Condition, Arendt claims that among the three human activities-labor, work, and action-it is only action that is political because it is done in the presence of other people. This means that the condition of action is plurality. ${ }^{1}$ The sphere of action is a sphere of plurality where we disclose ourselves to others and interact as distinct and free persons. Action discloses a world or the public realm in which every individual freely reveals his or her distinctiveness to others. Like action, politics is also based on human plurality and deals with "coexistence and association of different men." 2 Arendt identifies action with politics, in the sense that action is political and politics is action. It is political action. This identification means that Arendt's thinking about the world or politics proceeds from the actual events or actions taking place in the world and not from abstract concepts or ideas. However, unlike other political theorists

${ }^{1}$ Hannah Arendt, The Human Condition (Chicago: The University of Chicago Press, 1958), 7-8.

${ }^{2}$ Hannah Arendt, The Promise of Politics (New York: Schocken Books, 2005), 93.

(C) 2015 Yosef Keladu

http://www.kritike.org/journal/issue 16/keladu june2015.pdf

ISSN 1908-7330

(cc) BY-NC-ND 
who base their thought on empirical data, Arendt prioritizes the factical and experiential character of human life as an acting being in the world.

In her political theory, Arendt intends to liberate politics from the hold of abstract and universal truth. But, in so doing, as George Kateb argues, Arendt "subordinates practicality and morality to the aesthetic potentiality of politics." 3 Hence, Kateb charges Arendt with promoting an immoral politics. This paper argues that Kateb's charge is groundless and suggests that Arendt's political thought is inherently ethical. Following Andrew Schaap, I call Arendt's ethics as 'the ethics of worldliness.' ${ }^{4}$ However, unlike Schaap who considers Arendt's ethics only from the world-disclosing potential of politics that depends on action and judgment, ${ }^{5}$ I construe her ethics as coming from her thinking of the world and judging an action.

Ethics deals with human beings, their mode of being or what they are capable of, what they can do. Raymond Geuss uses the term ethics to refer either to "rules that contain restrictions on the ways in which it is permissible to act toward other people" or to the "whole way of seeing the world and thinking about it." 6 I take Geuss' second sense of ethics as a way of thinking about the world in what I construe to be Arendt's ethics. While worldliness is a technical term to designate the material condition of the world or the man-made condition of human existence. For Arendt, the world is not the nature or the earth, albeit it is needed to build a home and to preserve human life. The earth becomes the world in the proper sense only when "the totality of fabricated things is so organized that it can resist the consuming life process of the people dwelling in it." 7 In other words, it is only through human works that the earth becomes a place of worldliness. Therefore, in this paper, the ethics of worldliness would be taken to mean a way of thinking about the man-made condition of human existence.

\footnotetext{
${ }^{3}$ George Kateb, Patriotism and Other Mistakes (New Haven \& London: Yale University Press, 2006), 151.

${ }^{4}$ Alice MacLachlan describes Arendt's ethics as an ethics of plurality on the basis of the political character of human action. She argues that Arendt's theory of political action reveals her deep ethical concern for the condition of human life. See Alice MacLachlan, "An Ethics of Plurality: Reconciling Politics and Morality in Hannah Arendt," in History and Judgment, ed. by A. MacLachlan and I. Torsen (Vienna: IWM Junior Visiting Fellows' Conference, 2006), 3. Garrath Williams calls it political ethics because when we act in the world, we pay attention to the idea of responsibility and the on-going responsiveness to the world. Responsibility for the world is inherent in the action itself. See Garrath Williams, "Love and Responsibility: A Political Ethics for Hannah Arendt," in Political Studies, XLVI (1998), 940.

${ }^{5}$ Andrew Schaap, Political Reconciliation (London and New York: Routledge Taylor \& Francis Group, 2005), 53-69.

${ }^{6}$ Raymond Geuss, Outside Ethics (Princeton: Princeton University Press, 2005), 6.

${ }^{7}$ Hannah Arendt, Between Past and Future (New York: The Viking Press, Inc., 1961), 210.
}

(c) 2015 Yosef Keladu

http://www.kritike.org/journal/issue 16/keladu june2015.pdf

ISSN 1908-7330 


\section{Thinking about the World and Responsibility}

Before elaborating on Arendt's thinking about the world, it is necessary to look into what she means by thinking. Arendt claims that thinking is different from reasoning for two grounds. First, reasoning is seductive in so far as it is loaded with answers. In reasoning, people intend to find an answer for their own behavior, action and even belief. It is meant to justify something that ought to be un-thinkable. Ordinary people such as the Nazis and Adolf Eichmann justified their evil action by reasoning that they just followed the order. In our time, terrorists find the same reason behind their violent actions, whether religious or ideological. Second, reasoning is secretive. Arendt calls it 'ice-cold reasoning' because it is done in the loneliness of a fantasized world where one relies only upon him- or herself. Here, reason is 'inner coercion' for a self-justification or selfconfirmation that has no relationship with others, thus, fitting man "into the iron band of terror." 8 This is exactly what Arendt sees in the logicality of ideological thinking as displayed by totalitarian regimes, such as Hitler in Germany.

In contrast to reasoning, the precondition for thinking is solitude which is not the same with loneliness. A solitary man is alone with himself, while a lonely man, though in the midst of others, has lost the experience of being with others. ${ }^{9}$ It is in the condition of solitude that man exercises his capacity of thinking. Here Arendt turns to the exemplary figure of Socrates. In Arendt's view, Socrates is an example of thinker who knows himself before engaging in a dialogue with the interlocutoers. This means that knowing oneself is the condition for knowing to live with others. ${ }^{10}$ In solitude, Socrates is not alone but with himself because he is in a situation of a constant dialogue of the 'two-in-one' and the product of this dialogue interrupts the citizens' lives and drives them away from conformitywhether from opinion (doxa) or from socially acccepted norms or values or type of behavior. ${ }^{11}$ Thus, Arendt claims that thinking is done in solitude when it is "a dialogue between me and myself; but this dialogue of the twoin-one does not lose contact with the world of my fellowmen because they are represented in the self with whom I lead the dialogue of thought."12

\footnotetext{
${ }^{8}$ Hannah Arendt, The Origins of Totalitarianism (New York: A Harvest Book and Hartcourt Inc., 1951), 478.

${ }^{9}$ Ibid., 476.

${ }^{10}$ Hannah Arendt, The Promise of Politics (New York: Schocken Books, 2005), 21.

${ }^{11}$ Roger Berkowitz, "Solitude and the Activity of Thinking," in Thinking in Dark Times: Hannah Arendt on Ethics and Politics, ed. By Roger Berkowitz (New York: Fordham University Press, 2010), 241.

12 Arendt, The Origins of Totalitarianism, 476.

(C) 2015 Yosef Keladu

http://www.kritike.org/journal/issue 16/keladu june2015.pdf

ISSN 1908-7330
}

$((c))$ BY-NC-ND 
Since thinking is always related to the world, then it allows us to gain access to the world of appearances. Arendt appropriates Kant's distinction between intellect (Verstand) and reason (Vernunft) that is not merely empirical but also ontological. On its most fundamental level, Kant claims that, as quoted by Arendt, the distinction between reason and intellect lies in the fact that "the concepts of reason serve us to conceive (begreifen, comprehend), as the concepts of the intellect serve us to apprehend perceptions (Wahrnehmungen)."13 From Kant's perspective, Arendt claims that thinking is not the same as knowing because the goal of the intellect is cognition or knowing and the highest criterion for cognition is truth. However, that truth is factual because it is derived from the world of appearances or what is given to the senses. This factual truth depends on the evidence of the senses. While the goal of the faculty of thinking or what Kant calls 'reason' is to understand or think the meaning of what already exists in sense perception. The faculty of thinking takes for granted the existence of something in the sense perception and wishes to understand what it means for it to be. ${ }^{14}$ The implication of Arendt's appropriation of Kant's distinction between intellect and reason, Robert Burch argues, is that cognition and the thirst for knowledge never leave the world of appearances. In fact, whether it is common sense or scientific investigation, all are inherent in the world of appearances. The desire to know is the desire for the full presence of the object and so thought is essentially derived from and within the world of appearances. ${ }^{15}$

For Arendt, thinking is an unfinished process and employs neither history nor coercive logic. She refers the former to modern philosophy that absolutizes or universalizes its idea and the latter to the logical determinism of totalitarian ideologies. Since thinking is an unfinished process, then any thought that happens to emerge should be treated as partial and open to criticism, or as Burch puts it: "The end of thinking is the ongoing process of thinking itself, self-destructive in being ever self-critical and self renewing."16 Buckler calls Arendt's treatment of thinking as a "selfconsciously mediated standpoint," which presupposes an epistemological mediation and a temporal mediation. The former is necessary to avoid conceptual closure and open up the possibility of communicating the product of thinking; and the latter to avoid historical closure in order to

${ }^{13}$ Hannah Arendt, The Life of the Mind (New York: A Harvest Book and Hartcourt, Inc., 1978), 57.

${ }^{14}$ Ibid., 57.

${ }^{15}$ Robert Burch, "Recalling Arendt on Thinking," in Action and Appearance, ed. by Anna Yeatman (London: Continuum, 2011), 18-19.

${ }^{16}$ Ibid., 12.

(C) 2015 Yosef Keladu

http://www.kritike.org/journal/issue 16/keladu june2015.pdf

ISSN 1908-7330

(cc) BY-NC-ND 


\section{ETHICS OF WORLDLINESS}

recognize that political actions are meaningful regardless of their historical locations. ${ }^{17}$

This understanding of thinking is the entry point for Arendt's notion of thinking about the world. Arendt claims that thinking is a response to a call coming from the nature of things. Thinking is bound to the reality and takes its bearing from the world. Here Arendt turns to Walter Benjamin who had 'the gift of thinking poetically.' 18 This kind of thinking is like a pearl diver who goes down into the depth of the sea to unfasten 'the fragments' - the pearl and the coral-and carry them to the surface. In the same way, thinking poetically means delving into the depth of the past and bringing into the world of the living what was survived in a new crystalized form as 'thought of fragments. ${ }^{19}$ For Arendt, in order to think anew we must go beyond the traditional philosophy and methodology and let the fragments or the objects of the world reveal themselves and inform our thought. This implies a conviction that there is novelty in any event in the world. Thus, Arendt emphasizes the importance of getting into the events themselves or in her own words: "To look upon the past with eyes undistracted by any tradition' and to 'dispose of a tremendous wealth of raw experiences." 20 The reliable source for thinking about the world is the world itself because the world can be meaningful in itself.

Thinking about the world presupposes attentiveness to the events of the world and implies a 'political commitment,' a commitment to take responsibility for what is happening in the world. Human beings must get out of themselves in order to be aware of and respond to the reality of the world. ${ }^{21}$ Arendt believes that humans have the capacity for "building, preserving, and caring for a world that can survive us and remain a place fit

17 Steve Buckler, Hannah Arendt and Political Thought (Edinburgh: Edinburgh University Press, 2011), 8.

${ }^{18}$ Hannah Arendt, Men in Dark Times (New York: A Harvest Book \& Harcourt Inc., 1955), 205.

19 Ibid., 206. Seyla Benhabib sees the affinity between Arendt and Adorno because both have the 'Benjaminian moment' in their emphasis on the importance of going on thinking despite the break of civilization brought about by the Holocaust and the rise of the social in modernity. Arendt and Adorno believe that in the midst of a dark period, we must learn to think anew by liberating ourselves from the power of false universals and by being attentive to the actuality or the things that appear themselves. This is what Arendt calls "thought of fragments" or what Adorno calls "the primacy of the objects." Seyla Benhabib, "Arendt and Adorno: The Elusiveness of the Particular and the Benjaminian Moment," in Arendt and Adorno: Political and Philosophical Investigations (California: Stanford University Press, 2012), 33.

${ }^{20}$ Arendt, The Life of the Mind, 12.

${ }^{21}$ Margaret Canovan, Hannah Arendt: A Reinterpretation of Her Political Thought (Cambridge: Cambridge University Press, 1992), 11.

(C) 2015 Yosef Keladu

http://www.kritike.org/journal/issue 16/keladu june2015.pdf

ISSN 1908-7330

(cc) BY-NC-ND 
to live in for those who come after us." 22 There are two meanings of responsibility in Arendt's perspective. The first meaning refers to a sense of care for the world, which means to know or understand the world. In this context, Arendt, for Straume, is the most politically concerned of all political philosophers because of her emphasis on the importance of conceiving politics as the care for the human world. ${ }^{23}$ One of the most important task of politics is to keep itself open for a self-questioning, reflexive and ongoing discourse. That means, political institutions should facilitate the forthcoming of many different perspectives. In Men in Dark Times, Arendt writes:

... for the world is not humane just because it is made by human beings, and it does not become humane just because the human voice sounds in it, but only when it has become the object of discourse. (...) We humanize what is going on in the world and in ourselves only by speaking of it, and in the course of speaking of it we learn to be human. ${ }^{24}$

The second sense of responsibility has to do with the acceptance of the givenness or the affirmation of life in the world. Arendt speaks of the world as the givenness since we are born into an existing web of relationships. Arendt criticizes Rahel Varnhagen who attempted to deny her Jewishness for the sake of being assimilated into the German culture. Varnhagen thought that by thus assimilating herself she would show her care for the country where she lived in. The fact shows that Varnhagen failed in erasing her trace as a Jew. For Arendt, Varnhagen would succeed if she assimilated herself as a distinct Jew with her Judaism's heritage. She claims: "In order to really enter an alien history, to live in a foreign world, she had to be able to communicate herself and her experiences." 25 Being a Jew is a gift and Judaism is her givenness or her world. Thus, Varnhagen should be grateful and be responsible for her own identity and experience as a Jew. The acceptance of the givenness is a matter of grace. There is something in us that needs to be thanked for, that is, life because it is a gift given to us. Here, responsibility for the world is not something that can be demanded of us but is our response to the world. It is a 'burden to be borne

\footnotetext{
${ }^{22}$ Arendt, Between Past and Future, 95.

${ }^{23}$ Ingerid Straume, “The Survival of Politics," in Critical Horizons, 13:1 (2012), 114.

${ }^{24}$ Arendt, Men in Dark Times, 24-25.

${ }^{25}$ Hannah Arendt, The Jewish Writing, ed. by Jerome Kohn and Ron Feldman (New York: Schocken Books, 2007), 26.
}

(c) 2015 Yosef Keladu http://www.kritike.org/journal/issue 16/keladu june2015.pdf ISSN 1908-7330 


\section{ETHICS OF WORLDLINESS}

by human beings' because the world where we live in is "both an undeserved gift and an undeserved burden." 26

If life is a gift and the world is the givenness, then how is evil a part of human life in the world? How can we be grateful without justifying the evils? For Arendt, evil is neither deep nor demonic and so it does not infect the world at depth and make us despair about it. In order to fully understand this claim, let us turn to Arendt's discussion of guilt and collective responsibility. After the Holocaust, the question is raised concerning whether or not the ordinary German citizens assume collective responsibility for the crimes committed by the Nazis. Like Jaspers, Arendt affirms that they should be collectively responsible by virtue of their belongingness to a political community. However, unlike Jaspers who draws responsibility from his understanding of guilt, ${ }^{27}$ Arendt claims that the feeling of guilt is not the origin of political responsibility. Without doing something wrong, Arendt argues, there is no reason for people to feel guilty. Making guilt collective not only disregards the possible innocent people but also it diverts our attention from the actual perpetrators. It is a kind of "whitewash of those who had done something" because "where all are guilty no one is." 28 Therefore, when the ordinary Germans assured each other and the whole world that they felt guilty of what had happened during the Holocaust, they are either morally confused or playing intellectual games. ${ }^{29}$

For Arendt, guilt and responsibility must be distinguished from one another. In her postcript to Eichmann in Jerusalem, Arendt agrees that Eichmann should be condemned not for his political responsibility but for his guilt..$^{30}$ Of course, Eichmann is politically responsible, but in the court, his individual guilt or innocence must be the basis for condemning him. It is

\footnotetext{
${ }^{26}$ Mark Antaki, "The Burden of Grace: Bearing Responsibility for the World," in Quinnipiac Law Review, 30 (2012), 514.

${ }^{27}$ According to Jaspers, criminal guilt is related to the violation of laws - whether it is natural or positive law - and lawbreakers should haven been convicted by a court. This guilt meets with punishment. Political guilt belongs to all citizens who are presumed to bear the deeds of their government by virtue of their membership. All citizens should be responsible for the consequences of the misdeeds of their regimes. It meets with liability. Moral guilt is the personal responsibility one bears before one's own conscience either because one has done something wrong or conforms to an immoral system, because one is indifferent to the sufferings of others, or because one fails to resist a criminal regime. Metaphysical guilt occurs when people fail to show absolute solidarity with their fellow human beings regardless of their particular relations to them. Human solidarity brings a feeling of guilt to those who have done nothing to prevent the evil deed. See Karl Jaspers, The Question of German Guilt, trans. by A. B. Ashton (New York: Fordham University Press, 2000), 25-26.

${ }^{28}$ Hannah Arendt, Responsibility and Judgment, ed. by Jerome Kohn (New York: Schocken Books, 2003), 28.

${ }^{29}$ Ibid., 29

${ }^{30}$ Hannah Arendt, Eichmann in Jerusalem (New York: Penguin Group Ltd., 1963), 298.
}

(c) 2015 Yosef Keladu

http://www.kritike.org/journal/issue 16/keladu june2015.pdf

ISSN 1908-7330

(c) $)$ BY-NC-ND 
clear that for Arendt when we talk about guilt we always refer it to something that pertains to morality or law, whereas responsibility refers to politics. Thus, from the perspective of politics, responsibility should be understood in the context of either belonging to a political community or doing something. ${ }^{31}$ That means, one feels guilty because he is member of a community and has done something that offends the community where he belongs.

Arendt criticizes the European Jews who denied their Jewish heritage as a political identity and desired a change that would not compel them to act and, worse, would not compel them to voice out their opinion. According to Arendt, the European Jewish should have done something about what they had experienced as a political group by having their own opinion about what had happened to them. When she was challenged by Günter Gauss in an interview about her own situation where she left Germany and later became a USA citizen, Arendt defends herself by claiming that she at least has had an opinion since 1933. She responds to the challenge: "I tried to help in many ways (and) I must say it gives me a certain satisfaction. I was arrested ... I thought at least I had done something!" 32 Arendt is not a Zionist but her constant relationship with some prominent Zionist leaders gave her the chance to nourish her Jewishness.

For Arendt, responsibility is the link between individual deeds and belonging. This is clear in the story about Anton Schmidt, a German soldier who helped Jews to escape. ${ }^{33}$ The significance of this story is the fact that Schmidt was a German who knew the situation and did something. In contrast, another German, Peter Bamm, knew about the Nazi atrocities but did nothing. Arendt acknowledges that from a political perspective, even in the midst of terror there are some people who are able to act. ${ }^{34}$ Schmidt's action displays the link between action and natural givenness (being German), which is the most political dimension of responsibility. As a German, Schmidt was responsible for the crime committed by the Nazis,

${ }^{31}$ Annabel Herzog, "Hannah Arendt's Concept of Responsibility," in Studies in Social and Political Thought, (2001), 41.

32 Here Arendt refers to her involvement in the Zionist organization led by Kurt Blumenfield. Although Arendt was not a member of this organization, she was the one who put together a collection of all anti-Semitic statements. It was a risky task because to organize such a collection means to engage in what the Nazis called "horror propaganda." Thus, no Zionist could do that in order to protect the Zionist organization and Arendt joyfully took this job because it was an intelligent idea and it gave her the feeling "that something could be done after all." Hannah Arendt, Essays in Understanding, ed. by Jerome Kohn (New York: Schocken Books, 1994), 5.

${ }^{33}$ Arendt, Eichmann in Jerusalem, 231.

${ }^{34}$ Ibid., 233

(c) 2015 Yosef Keladu

http://www.kritike.org/journal/issue 16/keladu june2015.pdf

ISSN 1908-7330

(cc) BY-NC-ND 


\section{ETHICS OF WORLDLINESS}

although he was not guilty. Schmidt's action-taking initiative to help Jews-changes the meaning of his givenness, being a German. Thus, by assuming responsibility, Arendt argues, people are urged to act and their acts can change the human world, and this has an impact on what it means to be a member of a given political community.

\section{Judging Political Action}

Arendt's identification of action with politics is by no means unproblematic. It seems to be contradictory because on the one hand, she celebrates political action but on the other hand, she is fully aware of the destructive effects of political action as displayed by the Nazi regime in Germany. Thus, how do we properly understand Arendt's celebration of political action in the face of the violent actions? Here the importance of judgment comes to the fore.

\section{Reflective Judgment}

Arendt deals with judgment in her book on Kant called Lectures on Kant's Political Philosophy, where she appropriates the latter's aesthetic judgment. Arendt makes two important observations regarding Kant's third critique, The Critique of Judgment, that shed light on her own idea of judgment. First, Kant never elaborates truth, "except once in a special context" because for him human beings are not intelligible or cognitive beings; Kant always "speaks of man in plural, as they really are and live in societies." 35 Second, for Kant, the faculty of judgment deals with particulars, maintaining that the fundamental act of reason is judgment in general and the possibility of giving a judgment on a thing or an event has equal weight. For Kant, judgment bridges the gap between the phenomenal world and the noumenal order of being. ${ }^{36}$ Kant distinguishes between reason through which we recognize the experiential condition of knowledge and intellect that enables us to grasp the noumenal order. Thus, in judgment, we freely

\footnotetext{
35 Hannah Arendt, Lectures on Kant's Political Philosophy, ed. by Ronald Beiner (Chicago: The University of Chicago Press, 1992), 13.

36 According to Kant, there are two kinds of judgment, namely reflective and determinant judgments. In a reflective judgment, the particulars are given beforehand while in a determinant judgment, the universal is given and the particulars are subsumed under them. In the first introduction to the Critique of Judgment, Kant writes: "Judgment in general is the ability to think the particular as contained under it. If the universal (the rule, principle, law) is given, then judgment, which subsumes the particular under it, is determinate ... But if only the particular is given and judgment has to find the universal for it, then this power is merely reflective." Immanuel Kant, Critique of Judgment, trans. by Werner Pluhar (Indianapolis: Hacket Publishing Company, 1987), 18-19.
}

(C) 2015 Yosef Keladu

http://www.kritike.org/journal/issue 16/keladu june2015.pdf

ISSN 1908-7330

(c) BY-NC-ND 
act to recognize the experiential condition of knowledge within the noumenal order. ${ }^{37}$

Drawing from Kant, Arendt acknowledges that there are two meanings of judgment in our common usage that need to be differentiated. In a general sense, judgment is taken to mean, "organizing and subsuming the individual and particular under the general and universal." 38 In this judgment, the particulars or concrete events in the world are identified through the standards that we have formed in our minds. The following illustration can explain what Arendt means here. When we say that a woman is beautiful because of one, two, three or more reasons, our judgment of the beauty of that woman comes first from our own idea or concept that we have formed in our mind. It does not come from that woman who appears herself. Here, judgment is rendering the standard that may or may not be appropriate to measure the thing that we judge. Another kind of judgment that is completely different from the first one is the judgment of aesthetics and taste. This judgment arises when we are confronted with things, which "we have never seen before and for which there are no standards at our disposal." 39 The precondition for judgment is the evidence of what is being judged and the ability to make distinction. It is the things as they appear themselves before us that drive us to distinguish between the beautiful and the ugly, between right and wrong. This second sense of judgment is what Kant calls reflective judgment.

Arendt finds in Kant's reflective judgment a new standard for judging that no longer moves from the universal to the particulars but conversely from the particulars to the universal. That means, instead of applying the accepted standards and given rules to the particular situations, in judging we deal with objects in themselves. When we judge, we draw some new principles that involve new concepts coming from an individual thing or situation. ${ }^{40}$ Here, judgment is the ability to apply thinking into the particulars because judgment enables us to tell whether something is right or wrong, beautiful or ugly. It is "the manifestation of the wind of thought in the world of appearances." 41

Arendt's appropriation of Kant's reflective judgment, Fine claims, is tied to the notion of common sense and the enlarged mentality. For Arendt, Kant is distinguished from other philosophers because of his interest in the world of appearances or the world of plurality. Being with others is

${ }^{37}$ Max Deutscher, Judgment after Arendt (England: Ashgate Publishing Limited, 2007),

$\mathrm{xv}$.

${ }^{38}$ Arendt, The Promise of Politics, 102.

${ }^{39}$ Ibid., 102.

${ }^{40}$ Deutscher, Judgment after Arendt, 150.

${ }^{41}$ Arendt, The Life of the Mind, 193.

(c) 2015 Yosef Keladu

http://www.kritike.org/journal/issue 16/keladu june2015.pdf

ISSN 1908-7330

(cc) BY-NC-ND 
indispensable for Kant, which he relates to the idea of common sense. In Arendt's view, common sense allows the subjective judgment to be contrasted with the possible judgment of others, transforming those judgments into something universally valid or at least universally communicable. ${ }^{42}$ Arendt relates Kant's common sense to community sense, considered as capacities of the mind that enable people to participate in public life.

While Arendt admits the importance of common sense, we should not, however, overstate it and let it determine the content of our own judgment because common sense is only partially true. Here Arendt then turns to Kant's second idea of the enlarged mentality, taking into account others' points of view. Arendt calls Kant's enlarged mentality as "the train of one's imagination to go visiting." 43 This capacity is necessary for overcoming the subjectivity of our perception and making public the opinions for an ongoing discussion. From Arendt's own perspective, the enlarged mentality is, as Buckler puts it: "A capacity that becomes visible in the public realm as an opinion to be shared and discussed, a view that seeks the consent of others in non-ideally regulated discussion about how the world should be and what we wish to see in it." 44

\section{The Standard for Judging an Action}

Arendt's claim that reflective judgment proceeds from the particular events in the world and not from the universal standards is applicable as well in the realm of morality. In fact, she firmly claims that the absolute moral standards have collapsed in the tragedy of the Holocaust that marks the breakdown of our civilization. ${ }^{45}$ This collapse gives the impression that what we call morality consists merely of 'our habits' and is

${ }^{42}$ Robert Fine, "Judgment and the Reification of the Faculties: A Reconstructive Reading of Arendt's Life of the Mind," in Philosophy and Social Criticism, 34 (2008), 165.

${ }^{43}$ Arendt, Lectures on Kant's Political Philosophy, 43.

${ }^{44}$ Buckler, Hannah Arendt and Political Theory, 28.

${ }^{45}$ In her essay 'Some Question of Moral Philosophy,' Arendt analyzes traditional morality as encountered in the totalitarian terror of socialism or Marxism in Russia and Nazism in Germany. With regard to Marxism, she claims that the characteristic of Lenin's morality is that it is a "naïve belief that once the social circumstances are changed through revolution, mankind will follow automatically the few moral precepts that have been known and repeated since the dawn of history." Arendt, Responsibility and Judgment, 53. However, with regard to Nazism in Germany, the totalitarian regime of Hitler changed the moral standard of "Thou shall not kill' and 'Thou shall not lie' to 'Thou shall kill' and 'Thou shall lie.' Arendt writes: "Hitler's criminal morality was changed back again at a moment's notice, at the moment 'history' had given the notice of defeat. ... This sudden return to 'normality' contrary to what is often complacently assumed can only reinforce our doubts." Arendt, Responsibility and Judgment, 54 .

(C) 2015 Yosef Keladu

http://www.kritike.org/journal/issue 16/keladu june2015.pdf

ISSN 1908-7330

(c) $\mathrm{BY}-\mathrm{NC}-\mathrm{ND}$ 
no more than a set of mores, customs, and manners which could be exchanged with another set. Moreover, this set of mores, customs, and manners is uncritically accepted by ordinary people, in the sense that as long as moral standards are socially accepted, people never doubt what they have been taught to believe. ${ }^{46}$ What concerns Arendt is the uncritical mind of people who are easily accepting of any given moral standard. For her, following universal standards has the possibility of shutting down the thinking process. This can be seen in the trial of Adolf Eichmann who was described as someone who was unable to think. Eichmann's constant repetition of phrases that he would like to find peace with his former enemies was considered an indication of his inability to think. ${ }^{47}$

Furthermore, Arendt is also concerned with the secret characteristic of Christian goodness in the sense that whatever man does, the actor must not know the goodness of his or her act. It is only God who knows the goodness of an act and not the actor or even the world. In this way, Arendt argues, an action is judged good or bad not by the actor but by God. Consequently, the goodness or badness of an action is secretive because it lies in the mind of God and so is unsuited in the public realm. In fact, when this goodness enters into the world, it becomes corrupted: "Goodness that comes out of hiding and assumes a public role is no longer good, but corrupt in its own terms and will carry its own corruption whenever it goes." 48 Since the idea of goodness does not come from the self and the world, it represents the absolute purity that cannot be questioned or talked about. The absolute nature of goodness threatens not only the plurality of opinions that constitutes the public realm, but also the freedom of other actors. It becomes despotic because it tends to be destructive. Or as she puts in On Revolution, it "spells doom to everyone when it is introduced into the political realm." 49

What Arendt wants to demonstrate is that in the public realm, the goodness should not be the standard for judging an action because it indicates an inclination to legislate for politics from a vantage point that is outside of politics itself. Therefore, Arendt suggests that greatness, a principle generated in the action itself, be the standard for judging an action. Arendt relates action to the event of natality or birth, which she considers as arche, the principle of the beginning and of givenness. Both principles are coexisting and each gives rise to two different relations. The beginning gives rise to plurality and principle to singularity or uniqueness. Many people are born into the world, but each newly born introduces something anew to the

${ }^{46}$ Ibid., 54.

${ }^{47}$ Arendt, The Life of the Mind, 4.

${ }^{48}$ Arendt, Responsibility and Judgment, 77.

${ }^{49}$ Arendt, The Promise of Politics, 84.

(c) 2015 Yosef Keladu

http://www.kritike.org/journal/issue 16/keladu june2015.pdf

ISSN 1908-7330

(cc) BY-NC-ND 
world and appears to be a distinct and unique person. This means that the new beginning carries within itself its own principle that differentiates him or her from others. The unpredictability of an event of natality lies in the fact that the origin or the beginning carries within itself its rule or principle. That is exactly what happens in action. When one acts, one introduces something new, and as a new beginning, this action carries within itself a principle that makes it distinct from others. The unpredictability of action lies in the action itself as a new beginning that carries within itself its own principle. ${ }^{50}$

Arendt draws the term principle from Montesquieu's analysis of the nature of government and the principle behind its action. Montesquieu claims that the nature of government is what makes it as it is and the principle is what makes government act in a certain way. In this sense, the nature of government is its particular structure and the principle is the human passions that set it in motion. There can be many forms of government, but each form carries within itself a principle that underlies its own action. In the Spirit of the Laws, Montesquieu claims that a form of government is animated by a spirit or ethos, which is understood as the affection that provides the principle of its action. For instance, the republican form is animated by the principle of political virtue; the monarchical form by the principle of honor; and the despotic form by the principle of fear. ${ }^{51}$ From Montesquieu's perspective, Arendt claims that each principle operates 'from without' and exists in the world not as an abstraction but as an actual action which appears to others. That means each action reveals its own principle.

An action is tied to the individual through a principle, which the Greeks called archein: to originate, begin, or give a rule which is conditioned by this formative principle. This reveals the connection between the actor and the act, while the act itself combines the principle and its performance. "The greatest that man can achieve is his own appearance and actualization." 52 Thus, the principle is disclosed by the act in its performance and produces a novelty that only becomes intelligible after the fact. In this context, a principle is not an intention because it does not suggest a result

50 Peg Birmingham, Hannah Arendt \& Human Rights: The Predicament of Common Responsibility (Indianapolis: Indiana University Press, 2006), 82.

${ }^{51}$ Garrath quotes Montesquieu as follows: “... (political) virtue, being love of the republic and thence of the (political) equality it offers; honour, 'the prejudice of each person and each condition,' meaning ambitiousness within a statue hierarchy, offered by bodies intermediary to sovereign and people; and fear, which reduces every subject to 'a creature that obeys a creature who wants,' the despot, submission to whose whims constitutes the only enduring law." Garrath William Garrath, "Love and Responsibility: A Political Ethics for Hannah Arendt," in Political Studies, XLVI (1998), 943.

${ }^{52}$ Arendt, The Human Condition, 208.

(C) 2015 Yosef Keladu

http://www.kritike.org/journal/issue 16/keladu june2015.pdf

ISSN 1908-7330

(c) $)$ BY-NC-ND 
and offers no obligation to others. Unlike result and obligation that can be predetermined before the performance of an action, the greatest principle is only conceived after an action is performed and narrated in a story. She writes: "... the meaning of a committed act is revealed only when the action itself has come to an end and become a story susceptible to narration." 53

In Arendt's account, the arche only sets the action into motion without directing it. These principles illuminate action. Since political action concerns with the phenomenal world of appearances, then these inspiring principles become fully manifest only in the performing act itself. ${ }^{54}$ The principle as the specific meaning of action is identified after the fact by others who witness that action. One's action is judged by others or spectators to whom the actor appears. It is the recognition of spectators that gives meaning to the actor's deed and its significance for the common world. Without the presence of others who witness the actor's deed, the world in-between is not possible; and without the judgment of others, the meaning of action cannot be comprehensive. It remains partial because it depends only on the actor's own judgment.

\section{The Ethical Character of Arendt's Reflective Judgment}

Arendt's appeal to greatness as a principle that arises out of the performative action and the standard of judging a political action challenges the traditional and Christian moralities that tend to impose the universal and absolute moral principles to the realm of politics. This tendency is destructive or anarchic because it is a kind of "an escape from and the emasculation of, the inherently plural and conflictual sphere of politics." 55 Thus, the question that remains to be dealt with has something to do with the ethical constraint in Arendt's reflective judgment.

Arendt offers a judgment that is neither cognitive nor historical. It is not cognitive because it depends on the approval of others who have common sense. Judgment is not historical because it is not intended to posses a single judgment or choice, but rather it is always open for an

53 Arendt, Men in Dark Times, 82.

${ }^{54}$ Arendt beautifully writes: "Action insofar as it is free is neither under the guidance of the intellect nor under the dictate of the will-although it needs both for the execution of any particular goal-but springs from something altogether different which ... I shall call a principle. Principles do not operate from within the self as motives do ... but inspire, as it were, from without; and they are much too general to prescribe particular goals, although every particular aim can be judged in the light of its principle once the act has been started. For, unlike the judgment of the intellect which precedes action, and unlike the command of the will which initiates it, the inspiring principle becomes fully manifest only in the performing act itself ...." Arendt, Between Past and Future, 152.

${ }^{55}$ Buckler, Hannah Arendt and Political Thought, 126.

(c) 2015 Yosef Keladu

http://www.kritike.org/journal/issue 16/keladu june2015.pdf

ISSN 1908-7330

(cc) BY-NC-ND 


\section{ETHICS OF WORLDLINESS}

ongoing discourse. Arendt suggests that in judging we should take into account other people's points of view or our judgment should be directed to others. This implicitly implies respect for others because, like ourselves, other people are also acting and speaking persons. They possess every right to have an opinion of their own about anything in the world. In the interview with Günther Gauss, Arendt claims that her thought is always grounded in "trust in people ... a trust-which is difficult to formulate but fundamental - in what is human in all people." 56

Respect for other's points of view and trust in what is human in all people are actually interwoven in Arendt's writings. In fact, Arendt devotes so much attention to the individuals who not only did good and acted right but also bravely spoke in dark times about what is right and wrong. She discovers the latter in the figure of Socrates and other writers as discussed in her book Men in Dark Times who kept thinking and judging up to the point of sacrificing themselves for the sake of what they held to be right and good. They are the examples of people who still exercise their ability to judge in dark times because they "went really on their own judgments, and they did so freely; there were no rules to be abided by, under which the particular cases with which they were confronted could be subsumed." 57 The point is that Arendt still believes in the human capacity for judging things of the world.

The trust in the human capacity for judging implies that all human beings have this capacity in common and thus all people can judge from their different positions in the world. Consequently, any reflective judgment, albeit done in private and tied to a particular condition, is always liable to a common and ongoing discursive deliberation. In discursive deliberation one's own judgment is exposed to the public realm not to discover a cultural convention but rather to discover whether or not this particular reflective judgment is in accord with what is the best for the public realm. Buckler argues that Arendt's ethics cannot be assimilated with the communitarian thinking that appeals to the cultural convention as the ground for political ethics. This means that a set of shared or culturally inscribed conventions is considered as the basis for arranging the different perspectives about our common image of the good life at the political level. Although the cultural conventions no longer refer to the universal or absolute standards, they represent a kind of solidarity in belief, which is quite different from Arendt's emphasis on plurality. Consequently, Buckler claims that the communitarian grounding of political ethics would "threaten spontaneity and so neglect the political in favor of the imposition of a given

\footnotetext{
${ }^{56}$ Arendt, Essays in Understanding, 23.

${ }^{57}$ Arendt, The Promise of Politics, 295.
} 
set of ethical prescriptions." 58 For Arendt, the ethical constraint of all judgments is the greatest deed or word that endures and the most radiant glory that one reveals in the human world. ${ }^{59}$ Every time we pass a judgment on an action taking place in the world, we discern what is the greatest thing that action could bring to the public realm. In other words, in judging we are always conscious of the ethical constraints or imperatives that arise out of the public realm, which is the greatness of the public realm.

Furthermore, Arendt repeatedly claims that one's own judgment should be contrasted with other judgments or other points of view in an ongoing discussion. This process does not intend to attain an authoritative judgment, but rather to seek for the approval or disapproval of others who inhabit the same world. Here, the ethical constraint of Arendt's reflective judgment is not quite similar to a set of procedural principles. Of course, the procedural principles are derived from the process of public deliberations. This means that public deliberations produce a set of principles that carry substantive ethical authority that could provide criteria for the just arrangement of the institution in the polity. Although the procedural principles follow the practice of politics, Buckler argues that this process of public deliberation still appeals to the universal conditions of reflective judgment. This means that the point of reference is judgment, the citizens' faculty of passing judgment, and thus not necessarily the phenomenal conditions of appearance, which is central in Arendt's notion of reflective judgment. These phenomenal conditions "may provide a basis for political ethics, not because it presupposes substantive constraints but because it implies an understanding of how constraint might arise in the context of public realm itself." 60

Arendt acknowledges that one particular judgment has validity but is never universally valid. Thus, every partial judgment is subjected to the public gaze or the verdict of spectators. In other words, when we pass on judgment on a particular action, we anticipate what others might judge about that same action. We are conscious of the verdict that might come from others. For Arendt, when we contrast our judgment with others', we search for the meaning of all the judgments in the common world. It becomes clear that Arendt's ethics advocates action and judgment and since both are primarily defined by their reference to the public realm and other people, then the ethical constraints or the imperatives are inherent in the public realm and the verdicts of spectators.

The Graduate School, University of Santo Tomas, Philippines

\footnotetext{
58 Buckler, Hannah Arendt and Political Thought, 128.

${ }^{59}$ Arendt, Between Past and Future, 218.

${ }^{60}$ Buckler, Hannah Arendt and Political Thought, 130.
}

(C) 2015 Yosef Keladu http://www.kritike.org/journal/issue 16/keladu june2015.pdf ISSN 1908-7330 


\section{ETHICS OF WORLDLINESS}

\section{References}

Arendt, Hannah, The Origins of Totalitarianism (New York: A Harvest Book, Harcourt Inc., 1951). Men in Dark Times (New York: A Harvest Book, Harcourt

Brace \& Company, 1955).

The Human Condition (Chicago: The University of Chicago

Press, 1958).

Between Past and Future (New York: The Viking Press, Inc., 1961).

Eichmann in Jerusalem: A Report on the Banality of Evil

(New York: Penguin Group Ltd., 1963).

On Revolution (London: Penguin Books, 1965).

The Life of the Mind (New York and London: A Harvest Book and Harcourt, Inc., 1978).

Lectures on Kant's Political Philosophy, ed. by Ronald

Beiner (Chicago: The University of Chicago Press, 1992).

Essays in Understanding, ed. by Jerome Kohn (New York:

Schocken Books, 1994).

Responsibility and Judgment, ed. by Jerome Kohn (New York:

Schocken Books, 2003).

The Promise of Politics, ed. by Jerome Kohn (New York: Schocken Books,, 2005).

The Jewish Writings, ed. by Jerome Kohn and Ron Feldman

(New York: Schocken Books, 2007).

Antaki, Mark, "The Burden of Grace: Bearing Responsibility for the World," in Quinnipiac Law Review, 30 (2012).

Benhabib, Seyla, "Arendt and Adorno: The Elusiveness of the Particular and the Benjaminian Moment," in Arendt \& Adorno: Political and Philosophical Investigations, ed. by Lars Rensmann and Samir Gandesha (Stanford: Stanford

University Press, 2012).

Berkowitz, Roger, "Solitude and the Activity of Thinking," in

Thinking in Dark Times, ed. by Roger Berkowitz, (New York: Fordham University Press, 2010).

Birmingham, Peg, Hannah Arendt \& Human Rights: The Predicament of Common Responsibility (Indianapolis: Indiana University Press, 2006).

Buckler, Steve, Hannah Arendt and Political Theory: Challenging the Tradition (Edinburugh: Edinbergh University Press Ltd., 2011.

Burch, Robert, "Recalling Arendt on Thinking," in Action and Appearance, ed. by Anna Yeatman (New York: Continuum, 2011).

(C) 2015 Yosef Keladu

http://www.kritike.org/journal/issue 16/keladu june2015.pdf

ISSN 1908-7330

(cc) BY-NC-ND 
Canovan, Margaret, Hannah Arendt: A Reinterpretation of Her Political Thought (Cambridge: Cambridge University Press, 1992).

Deutscher, Max, Judgment after Arendt (Hampshire, England: Ashgate Publishing Limited, 2007).

Fine, Robert, "Judgment and the Reification of the Faculties: A Reconstructive Reading of Arendt's Life of the Mind," in Philosophy \& Social Criticism, 34 (2008).

Geuss, Raymond, Outside Ethics (Princeton: Princeton University Press, 2005).

Herzog, Annabel, "Hannah Arendt's Concept of Responsibility," in Studies in Social and Political Thought, (2001).

Jaspers, Karl, The Question of German Guilt, trans. by E.B. Ashton (New York: Fordham University Press, 2000).

Kant, Immanuel, Critique of Judgment, trans. by Werner Pluhar (Indianapolis: Hacket Publishing Company, 1978).

Kateb, George, Patriotism and Other Mistakes (New Haven \& London: Yale University Press, 2006).

MacLachlan, Alice, "An Ethic of Plurality: Reconciling Politics and Morality in Hannah Arendt," in History and Judgment, ed. by A. MacLachlan and I. Torsen (Vienna: IWM Junior Visiting Fellows, Conference, Vol. 21., 2006).

Schaap, Andrew, Political Reconciliation (London and New York: Routledge Taylor \& Francis Group, 2005).

Straume, Ingerid, “The Survival of Politics," in Critical Horizons, 13:1 (2012).

Williams, Garrath, "Love and Responsibility: A Political Ethics for Hannah Arendt," in Political Studies, XLVI (1998). 